\title{
The Hidden Truth Behind the Forms of Beauty in Margaret Atwood's The Handmaid's Tale
}

\author{
Sara Rasul Namiq \\ Iraq, Sulaimanyah \\ sara.rasul.namiq@gmail.com \\ Chalak Ghafoor Raouf \\ Department of English Language and Literature University of Human Development Iraq, Sulaimaniayah \\ chalak.raouf@uhd.edu.iq \\ ORCID ID: 0000-0001-9055-5867 \\ Assistant Lecturer / Department of English Language and Literature. B.A In English Literature, and 5 published \\ research papers in the field of English Literature
}

\begin{abstract}
-this paper theorizes the latest forms of the patriarchal control through analyzing Margaret Atwood's The Handmaid's Tale. The paper tries to assume that women in the post-modern age are no longer controlled through the traditional forms of control, but, they are controlled through the forms of beauty such as makeup, fashion, and plastic surgery. Instead of confining women at home, and oppressing them so as to control them, male-dominated societies nowadays are controlling women through beauty experts and their productions. Thus, women are no longer confined at home, and they are no longer oppressed, but, they are working side by side with their male counterparts, and making money just like them, but the problem is that they are spending their money on the forms of beauty. In this way, male societies give women a limited freedom as a key strategy for manipulation in the first step, and then, they try to keep them busy with the forms of beauty so as to make them remain under control. From the late nineteenth century to the post-modern age women have faced numerous challenges. They have been subdued and introverted by the male forms of power, but due to the Industrial Revolution, the technological advancement, and the two world wars, females have been able to open their eyes and see the reality around them. Though, even till this day they are living for the purpose of men and are becoming a symbol for pleasure and an ornament of decoration through the different forms of beauty. So, what this paper tries to do is to discover the hidden truths behind the forms of beauty, and theorize these forms as the latest tools of patriarchal control in the post-modern age.
\end{abstract}

Keywords-women, post-modern age, forms of beauty, control. I. Introduction:

The late 19th century to the post-modern age is a period that symbolizes the change and hypocrisy of male power towards women, as they were repressed within the inner walls of their own home. They were obliged to follow the patriarchal beliefs of their society at that time: to accomplish the image of the ideal women. Therefore, women were considered as subjects to the laws and regulations imposed upon them by men. During this era "women were only viewed as people that should only concern themselves with keeping a successful household" (Barrett 3). Their main job was to be good housewives and mothers to their children, nothing more was expected from them, as the society believed that they were not capable of anything else. This belief can be seen clearly in Alfred Tennyson's poem The Princess as he says:

Man for the field and woman for the hearth:

Man for the sword and for the needle she:

Man with the head and woman with the heart:

Man to command and woman to obey (437).

These perpetual words simply places women where she ought to be, which is functioning her household. Women were treated inferior to men as Gallagher states in his work, "whatever their social rank, in the eyes of the law women were second-class citizens" (57). This ideology of Victorian society believed that a woman's proper and only place was within their household, in this way, they would ultimately become the accomplished women.

\section{A. Industrial Revolution}

"The Industrial Revolution is traditionally associated with the late eighteenth and early nineteenth centuries. It has long been seen as the great historical turning point in the nature of women's working lives" (Berg 1). This is because the male institution called for women to work in factories to develop their country. In this period, women lacked freedom as well, and their condition at the work enforcement wasn't any better. Wanda Fraiken Neff illustrates numerous issues of women working at that time, as she says; "not only were working women regarded as a problem. All women were a problem" (Neff 11). This statement clearly undermines the mentality of society during that era. At that time, women were employed "in the lowest paid, least stable, and most unrewarding occupations" (Goodman 608). This is just because of pushing them away from power, and this view of the society never changed as their mentality believed motherhood is the utmost importance (Johnson 1). 
In some ways women were not only equal to men, but were even better, hence women were forced out of the public work arena by men who believed that their position of power to be threatened (Goodman 608). Additionally, women workers were considered better workers because of their product output and worked for less. Men were afraid that women have improved their abilities, and could potentially replace them. Jordan Goodman in his work Women's Work, Gender Conflict, and Labour states that; "Men began to feel the threat of the working woman was having on their jobs and they pushed for the idea of the family wage in 1880s and 1890s" (Katie 3). So, women were helped and supported by middle class citizens as the middle-class often argued that man should be the "breadwinner" for the entire family (Goodman 623).

\section{B. Stock Crash}

Women's condition started to change immensely after the Stock Crash 1929, as once again women had to leave the work force until all men were employed. The Wall Street Crash that marked the beginning of the Great Depression, as banks were closing their doors, industries had to cut their production (Langee 44). In this way, the Stock Crash affected everyone as "Industrial productivity declined, unemployment rose, and consumer spending dwindled and the nation's finances were in difficulty" (King, Marvin, Weitzman and Dwiggins 487). As a result, men also lost their jobs, but it was women who were once again confined, and obliged to stay within their household and take care of their family.

During the first year of "The Great Depression" many businesses agreed not to cut wages, however after the first year they lost all their savings, which meant that employers were practically forced to fire employees (May 133). Since women were only given unskilled jobs they were the first to be fired from their jobs. Although, they were employed in "low-paid service, sales, and clerical jobs" (Goldin 789). Some believed that sacking women from their jobs was very beneficial as they could be replaced by the unemployed men, and this step reduced the number of unemployment whilst in reality, the jobs that women took were jobs men rejected as most of the women's jobs were domestic work or they worked as teachers, nurses and office work.

According to the statistics of the Bureau of the Census that made by Goldin, the rate of unemployment immensely decreased as the number of unemployed workers reached 3.2 percent. This number grew year by year by the end of the great depression in 1933 it reached 23.6 percent (73). This once again reinforces the idea of how women were obliged to leave the work force because there were not enough jobs for the men, and during this patriarchal society, it was best for women to stay in the place that they belong to, which is their homes.

\section{World War Two}

During the WW2 millions of men enlisted for the armed forces to protect their country, which meant that, there were many jobs available, but not many men to cover all those jobs. The United States government recognized the availability of women on the home front, therefore, the government assigned the Office of War Information (OWI) the responsibility of enticing women into "war jobs. Since the government is in desperate needs, it will do anything to get women on bored, by making false accusations and enhancing propaganda campaigns to advocate to women how beneficial this would be to their country.

Additionally, employers were also in desperate need for women to return to the work force since there were not enough men to cover all the businesses. By creating ads appealing specifically to middle-class women, magazine advertisers hoped to recruit women who did not need to seek employment for wages, but would instead work solely for the benefit of the country. In this way, through these advertisements the government would get through to women.

Nearly "350,000 American" women served in uniform, both at home and abroad (Mai 2). These women took office and clerical jobs in the armed forces in order to free men to fight. In this way, women were employed as truck drivers, ambulance drivers, repaired aero planes and much more. Ironically, even though they were participating in men's work during the war, but they were receiving forty percent less pay than men (2). So, we can conclude from this point that no matter how good women are, they will always be seen differently and less when compared to men.

Propagandists soon came to develop "praising" women for their hard work and helping their country in desperate times. Such ads conveying to them that leaving the work force and returning to the domestic sphere was a hard- earned reward for participating in the war effort (Honey 123). A Smith-Corona Typewriter advertisement proclaimed "like our fighting men you've earned the right to choose the work you enjoy" and advised women to learn to type and take secretarial work after the war, suggesting that women would prefer working in offices rather than in factories (Honey 92). These types of advertisement is the first step of sending women back to their domestic lives, by telling them you are better suited to work in offices. Later advertisements encouraged women to once again leave the work force and be a mother to their children as their absence can have a great impact on their family life and society. So, after the Second World War ended, men came back from the battlefields, and asked for their jobs which were given to women. As a result, women once again lost their jobs and were sent back home.

After the technological advancement that manifested itself in the appearance of washing machine, vacuum cleaner, and television, women could find free times to think about their problems, and have access to information and knowledge through radio and television. In this way, women could open their eyes, and ask for their rights.

After women realized the way they were manipulated by men, they no longer considered the patriarchal speeches of their society. As a result, the male societies tried to develop their techniques for controlling 
women away from the traditional tools of control like confinement, separation, and repression. In this way, the forms of beauty appeared as substitutes for the previous tools so as to keep women under control in the post-modern age.

\section{The Handmaid's Tale and the Forms of Beauty}

Being affected by the injustice and the repression of women in the modern and post-modern age, Margaret Atwood, wrote The Handmaid's Tale. In this novel, Atwood portrays a clear picture of women's miserable condition in her society as a kind of resistance to the male-power. In the text, she presents the evolution of the patriarchal tools of control through the events that happen around Offred. After, the commander fails to control Offred through separation, confinement, surveillance, schedule, and language manipulation, he changes his techniques for controlling Offred. He starts to employ new tools for controlling her like beauty magazines, fashion, and makeup.

\section{A. Magazine}

As soon as the Commander realizes that he is no longer able to be in command of Offred through the traditional forms of control, he tries to make some changes in the forms of control since Offred is a rebellious character just like Moira. So, he resorts to the forms of beauty such as fashion, makeup and plastic surgery. First of all, the Commander hands Offred a "Vogue... magazine to read as to magnetize Offred to the forms of beauty" (Atwood 136). In one stance the magazine shows the freedom of women in the pre-Gilead society, but at the same time that freedom is put to the pleasure and use of men. In this case, the magazine symbolizes the control of Offred without her realizing. Offred believes that the Commander is being nice to her and is giving her a "present", but in fact the commander wants to maintain Offred and keep her under his wing by making her trust him, whereas the real truth is to make Offred busy through the use of the forms of beauty, and taking care of her appearance (Atwood 135).

The magazine was a "women's magazine... [about] fall fashions" (Atwood 135). The new trends that season women were egger to get their hands on to look trendy and up to date. The presence of the magazine made Offred to itch with passion, it made the "ends of [her] fingers ache" as she longed it with "force"(Atwood 136). As "Offred [stared] at the magazine, he dangled it before [her] like fish bait" which evokes the reality that this magazine is the "bait" that will lure Offred into doing what the Commander wants, therefore, she will be under his supervision. It is absurd how this magazine was once the "device to fill in empty time" which reinforces the fact that the forms of beauty have taken up women's time, simply a women's magazine is full of fashion and makeup tips as well as celebrities who have completed many plastic surgery sessions invoking the minds of women to appear in such way and to undertake such procedures (136).

In fact, women's magazines create a centre of attention. They are symbols of time being wasted, whilst they withhold all the forms of beauty that create a mass advertisement for women, showing them the image of an ideal woman. These magazines are running the fictional lives of females that will be unreachable goals for most women, hence, only wasting their time and money instead of embracing their knowledge and advancement. The reality of women is made into a "competition...so that women will be divided from one another" just like Gilead (Naomi 20). This separation indicates that women are controlled and cannot be united as one, as they are constantly in competition with one another, though they are of the same sex.

Women's minds are skilled to compete with each other since beauty drives all women apart from one another, whilst at the same time it binds them all together, as they all have one goal to reach; to become the ideal women. Additionally, women are not only competing with one another, but also "with "their younger selves" ...these women are driven by an unhealthy belief that winning the looks competition will somehow gain them the husband, the career, or the self they desire" (Barash 89-91). Even though this "vogue" magazine is a sign of the forms of beauty not only does it harm women, but causes a negative force between them, and builds hatred towards one another. So, this is not accident that so many women feel this way as "images of female beauty [are used] as a political weapon against women's advancement" (Naomi 16).

Hamilton Turner in his work The influence of fashion magazines on the body image demonstrates that "women's body image satisfaction is, indeed, influenced by their exposure to the thin ideal presented in magazines" (603-614). What we need to remember is that "more often than not, the images these women are seeing have been computer-edited and their models have been airbrushed and piled with makeup to camouflage any slight flaws that may, in reality, exist" (Scott 3). The ideal image of women changes year over year. Thus women can never reach the desired goal. In this way, woman need to keep changing their appearance, indicating that they are constantly kept busy with their looks. The ideal woman needs to have "golden hair united to brown or hazel eyes, soft, smooth skin with faint olive shading, little color in the cheeks" (Laura 22). These features need work day and night, and oblige women to spend their money on the forms of beauty.

Susannah Walker recognizes the irony of magazine advertisers as "Advertising and consumer culture have presented the human body as malleable and always in need of improvement. At this point, advertisements have offered people a narrow body ideal to strive for, and a limited route to achieve it: through the purchase of specific goods and services" (8). All this will overwhelm women "for the most part, what a woman observes in the mirror is what she uses as a measure of her worth as a human being" (Lerner, Karabenick, \& Stuart, 119-129). In this way, women compare themselves to the ideal images being presented in magazines, and this will break them, while trying to change their appearance.

On the opposite scale what one needs to remember is that women will become insecure, anxious along with low self-esteem since they are in constant completion with their 
own body to appear as the ideal women "The majority of research on women and their self-esteem has historically been related to how they feel about their body shape and size" (Scott 3). One could say that the magazines do not advertise how women could gain their self-esteem back and become more comfortable in their own bodies, but rather implements them to use makeup such as foundation, mascara, lipstick etc as this is a temporarily solution to improve one's appearance and imperfections.

\section{$B$. Skincare and Makeup}

Women were always exposed to fashion and makeup from an early age, hence, it was indoctrinated in their minds as long as you look like those women on the cover of magazines you will be "bold, striding, confident, their arms flung out as if to claim space" (Atwood 137). Offred's first glance at the magazine reminds her of the "images of [her] childhood" (Atwood 137). In view of the fact that women adored looking like women on the cover of magazines, as they knew only such women could be empowering. This made it easier for men to actually take control, because in the back of their mind they knew women will always want to look good, therefore, handing such magazine to Offred eventually means that she will try to take care of herself and request for more beauty products to maintain her appearance and keep it young looking. This is evident as it is after the commander handed her the magazine she felt the urge to ask for a "hand lotion" to keep her skin soft, supple and moisturized (Atwood 138).

The handmaids seem to be taking care of their skin secretly by stealing "a part of butter" or margarine to keep their skin supple (Atwood 58). Since there is no "hand lotion or face cream" the Handmaid's will resort to anything to maintain looking young (84). Therefore, in this case Offred "rub[s] butter over [her] face, works it into the skin and [her] hands" (84). This denotes that the handmaids actually take care of their skin because they still have the mentality that if they don't look attractive, then they will not find love. In addition to this, the handmaids have a current example of the wives, since the Commanders' wives are old, and have lost their physical beauty, and they "don't seem to have much in common, these days" (Atwood 138). Also to note, Offred asks for either "hand lotion" or "face cream" two parts of skin that are on show, implying it's all about the appearance and to maintain the young looking skin. Inevitably, all this is done for the pleasure of men. They want to be touched one day and remain attractive. In this way, just like the way Offred is accompanied by the commander, the handmaid's will be accompanied by men.

\section{Fashion and Body}

This is all from past experience as the magazines only display young and attractive looking women, whilst believing in the idea that "Strong men battle for beautiful women, and beautiful women are more reproductively successful. Women's beauty must correlate to their fertility, and since this system is based on sexual selection, it is inevitable and changeless" (Naomi 18). Even though the men in control have erased their past memories into believing they are made for reproduction only, and if they do not take care of their skin, then, they will not be loved or liked by any men. As long as women "butter their skin to keep it soft", therefore, they believe that one day they "will be touched again, in love or desire" (Atwood 84). This proves that women live their life in order to impress men, and all this pain they go through is solemnly just for the pleasure of men.

As soon as the bell rings, the handmaids need to wear their red uniform. The colour red is supposed to be sexy and bring out the spark within individuals, whilst at the same time it attracts men. In spite of this, the handmaids are wearing a modest smock dress as to not reveal their body since they are hired as sex workers, and are being childproducing machines.

Maria Davidenko in her work Discipline and Power in Women's Beauty Practices in Post-Soviet says; "women's demands for equality pose a threat to the status quo of masculine privilege as more equal gender relations automatically turn women into capable competitors" (5). Therefore, men tried to distract women and lead them astray from political power, so women were given the freedom to dress the way they want. The same thing happens in The Handmaid's Tale. After, the commander loses control over Offred, he gives her a limited freedom so as to be controlled through fashion.

Seeing the group of Japanese women's "skirts reach just below their knee and legs came out from beneath them, nearly naked", greatly influences Offred (Atwood 25). Their clothing turns heads as they wear "high-heeled shoes with their straps attached to the feet like delicate instruments of torture", and this shoe will enable women's "buttocks" to stick out causing heads to turn (25). Ofglen too stops to stares at these women, as she too is fascinated by their fashion and makeup. The two women "cannot take [their] eyes off these [Japanese] women", imagining how the men will react to such posture and clothing (25).

Kerry in his work states that; "in the 1920s, women's bodies became a part of the visible consumer culture. The female body was no longer just a physical body, but a cultural display" just like it is in the post-modern age (15). Women's bodies as shown in Gilead does not belong to women, but instead it is the possession of the male society. In Gilead the female bodies belong to the Commanders in charge, whilst in the post-modern age the female body is at the service of all the men. Either way, women are not even in control of their own bodies, "attention and sexuality, however, are defined by a male gaze. By attempting to use sexual display as a form of power, women actually fashioned themselves as sexual objects, yielding their power to the male gaze" (82).

Offred has a moment of self-awareness as she "used to dress like that", it is from this moment she realizes how Gilead has changed their perspective and "taken so little time to change [their] minds, about things like this" (Atwood 25). After seeing the Japanese women, Offred is ashamed of what she is wearing which is an exact reflection of the post- 
modern society. When someone sees women of such high fashion, may feel an immediate repulsiveness towards herself, and will try instantly to imitate those ladies of fashion. All because the media has placed pressure on women to look like the ideal women not thinking about the consequences. If all women looked like the ideal women, they would all look the same, as well as losing their originality and their own identity. They will not be the ideal women, but an unidentified woman.

Offred is "mesmerized by the women's feet" as they are wearing what their hearts desired, and she believes that this expressing their freedom even through their clothes as they wore "open-toed sandals, the toenails painted pink", the "smell of nail polish has made [Offred] hungry" as she now "remembers the smell of nail polish" (Atwood 26). Offred is "hungry" to look like these women, to gain her freedom back as she used to do all these things.

Offred is so desperate and fascinated by these women she "can feel her shoes, on [her] own feet" (Atwood 26). This obsession is visible in post-modern society when longing to look like those women on social media that they see themselves in their clothes. The Japanese women displayed "bare backs and shoulders, on the street, in public and legs, not even stocking on them, no wonder those things used to happen" (Atwood 47).

This inclination that there is something wrong with Offred's face, is a problem that needs to be fixed, and needs time to be fixed. The commander's words simply reinforce the notion of women being the object of males. Offred tries to look her best for the nightclub as she uses "a lipstick... eyeliner and mascara" whilst using the "vegetable-oil hand lotion" as a makeup remover" (Atwood 209).

Sarah Scott believes that "cosmetics serve as a sign of femininity in their symbolization of stereotypical feminine values" (4). They are often seen as a way to "enhance feminine beauty ideals and serve to help women to conform to our society's beauty expectations. As cosmetics companies present the made-up face as ideal, many women use makeup as an attempt to conform to these images of ideality" (Scott 4). In this way, women are placed under pressures to meet the requirements of beauty, so as to attract the opposite sex, and become an idol for other females (281298).

Knowing the nature of females, the Commander "holds a large silver-backed hand mirror" to show Offred that she looks "terrific now, after taking so much care of herself" (Atwood 209). The Commander wants to prove to Offred and other women that you look better with makeup. After Offred dresses up, and looks in the mirror, she creates a beautiful image of herself in the mind, and remembering always that she wants to look like this.

Another industry that took advantage of the political and economic crisis in the male societies was fashion and modeling. Beausoleil in his study Makeup in Everyday Life: An Inquiry into the Practices of Urban American Women of Diverse Backgrounds, states that "many women reported having different makeup routines depending on what they expect to do during the day" (33). The women in the nightclub are "tropical", as they are all in bright colours and all are wearing "makeup" suggesting that all those who come to nightclubs should not come to parties without makeup because they "appeared hyper-sexualized (Atwood 212). Wearing leg-baring dresses, noticeable makeup, accessories, and "exotic" colors and patterns, she eluded an aura of sexuality. In wearing "Oriental" styles, women capitalized on the exotic appeal of "the other" (Kerry 82-83). Therefore this is an indication to all women out there, they will need to spend much more time on their appearance whilst trying to attend a party. At the same time, men are all in "dark uniforms or suits", they all look "similar" implying that men don't need to change their appearance or spend more time if they attend a party, they come as they are (Atwood 212).

Additionally, women are still being controlled even in the nightclub, as they are reserved for men. The only difference between Gilead and the nightclub is the ability of dressing up and putting makeup on. Furthermore, Offred dressed in this way suggests that men will "review [her] breasts...legs", as they are only there for decoration (Atwood 213). Women were not employed for their skills and experiences, but for their physical appearance, as this would bring more income to the owner since men would come just for entertainment. So, a women's physical appearance will mean more profit. One might think if women dressed feminine and wore ladylike clothes with a lot of makeup they would be the ideal candidates for the job.

Even in western countries nowadays they want to higher women who look the part, and will get the attention of customers. In this way, they are working, but are kept busy by wasting their time on appearance. So, this is a win, win situation because women would be fired from their jobs, and were replaceable just like the handmaids. If the handmaids could not provide children for the commanders, then, they were disappeared and replaced the next day by another handmaid.

Additionally, this was true for all women, even though Serna Joy was respected on the surface level, but she was put to aside as she couldn't complete her role as a wife. A handmaid took her love life, and completed her roles as a wife. All this because Sera Joy couldn't provide a baby, and also because she was getting old, and "aging in women is un- beautiful" (Naomi 20). Aging women were not the ideal image of men because they had a lot of wisdom with experience, and with this, they could challenge the men. So, before they could spread their wings they were to be stopped by firing them from their jobs, in this way, they will not have stable living standards, and will focus on survival instead of resistance.

A further finding of this study was that "the more women appeared to believe in the beautifying effect of cosmetics, the more makeup they tended to apply on a daily basis" (Cash, et al., 2006 p. 494). This is an important realization, especially for the beauty industry and the marketing of the products within the industry. Since women believed in such ideas, they will go to extremes to achieve it. 
They tend to apply more make up on the daily basis which means that they will spend more time in applying their makeup, hence, less time to do together things.

In this way, women are not only kept busy, but also what they gain from their jobs they inevitably give back to men, as they spend so much on cosmetics, and making the men's economical status much better. It is like a vicious circle. Apparently they are free and could do anything they want, this is in the mind of the female since they could wear what they want and do what they want. For men, this is the optimization of their ability as they have women controlled in the sense that women could work, but they are still viewed different compared to men, and dressing and wearing makeup the way they want is only for the sexual purpose of men.

Just like the women in the Jozzebels, since they were rebellious and were not controllable, they were placed in the nightclub to give pleasure to the men. "Beauty, indeed," writes one journalist, "and the preservation of beauty have always...been subjects of deepest thought to women, with the two main purposes of making a favorable impression on men and of outshining all possible rivals of their own sex" (Kerry 74). Women are serving the men whilst kept busy. When women work, they gain their own money, but in reality, they spend it on what the men advertise, and this leads back into the men's pockets.

Advertisement does help, as they want to make money out of women. So, women are their source of profit. Companies produce these products for women to buy. This is almost like invading the premises of females in all possible direction as these advertisements reach everywhere. Where they are out and about, there are ads so there is no hiding away from it. These advertisements reach women within their homes as it's constantly on repeat of televisions. The scary thing is that women will go to the next world and back in order to achieve their ideal image.

\section{Plastic Surgery}

Since women are so influenced by men and their opinions, they will undergo plastic surgery as they would pump their bodies full of silicone, they would place themselves under the knife and needle just to enhance their physical features to attract men's attention. According to Naomi, "silicone breast implants were routinely inserted into women's bodies, and pornography was influencing popular culture in such a way that women were newly anxious about the size and shape of their bodies" (10). As a result, through women the economical status of men are improved, as women was the source of their income since beauty regimes took over women's lives.

As "surgery became a new ad market for women's magazines", women started to have "their nose cut off" to try to make their face more attractive, and create the perfect structure (Atwood 196). This is a kind of physical torture for women, however, they have such a strong image of the ideal women implanted in their brain.
Away from nose cut off, "women relied on external devices such as corsets to create the illusion of a perfect figure" (Kerry 15). Which is now an apparent in the modern age where celebrities are advertising corsets for a slimmer waste, and over time it will be slim without surgical procedures. This indicates the pain women will have to go through a long period of time until their desired goal is reached. "The corset was a symbol and physical manifestation of a woman's submissiveness and fragility. It was also a visual indicator of class and status as no workingclass woman could wear such a restraining garment while working as a factory girl or domestic servant" (15).

Nowadays, women are working freely, and for the most part work side-by-side to men. This means that women have their freedom compared to their previous years. Now women can work and have their own income, which enables them to build their own character, and stand on their own feet to depend on themselves. As a result, the male dominated society needs another way to take control; hence, beauty experts and the forms of beauty appear as the latest tools for control. Women work just like men do, however, women spend their hard earned money on the forms of beauty, since men have made sure that women look better with makeup as images of young and attractive women are plastered everywhere.

\section{Conclusion}

This paper dealt with discovering the hidden truth behind the forms of beauty in post-modern age through analyzing Margaret Atwood's The Handmaid's Tale. The paper assumed that after the changes that happened in the social and cultural position of women from $19^{\text {th }}$ century to the postmodern age, the patriarchal societies lost their control over women. Thereby, they were unable to control women through the traditional forms of control like separation, isolation, confinement, discipline, surveillance, and language manipulation. As a result, they had to invent new tools for control in order to suit the age; hence, they used the beauty experts to produce different forms of beauty so as to be used as new tools for controlling women. Through these tools, the male societies kept women in a state of busyness in order to keep them away from power, and at the same time, forget about their miserable conditions. The patriarchal societies realized that they cannot confine women in home anymore; so, they had to give them a limited freedom, as a key strategy for the new forms of control. Depending on this belief, nowadays male societies of post-modern age allow women to work side by side to men, and get money just like them, but at the same time, they oblige them to spend their money on the forms of beauty like makeup, fashion, and plastic surgery. Thus, women are living in a condition of busyness in which they work and get money from the male-dominated societies, but at the same time, the money goes back to men after women spend their money on the forms of beauty. So, what happens in Atwood's The Handmaid's Tale is just a record that theorizes the development of the patriarchal tools of control. 


\section{Works Cited}

[1] Atwood, Magaret. The Handmaids Tale. London: Random House, 1986. Print.

[2] Barash, Susan Shapiro. Tripping the Prom Queen: The Truth About Women and Rivalry. St. Martin's Press. New York City. 2006. Print

[3] Barrett, L. Kara. "Victorian Women and Their Working Roles". State University of New York College. Buffalo: 2013.

[4] Beausoleil, N. "Makeup in everyday life: An inquiry into the practices of urban American women of diverse backgrounds. In N. Sault (Ed.), Many mirrors: Body image and social relations". New Jersey: Rutgers University Press. USA: 1992.

[5] Berg, Refresh. "Women's Work and the Industrial Revolution". Vol.12. New York: 1991.

[6] Cash, W. David. "Scale and cross-scale dynamics: governance and information in a multilevel world". Ecology and society. Cape town: 2006.

[7] Gallagher, Catherine. The Industrial Reformation of the English Fiction. Chicago: UP of Chicago, 1985. Print.

[8] Goldin, C. and Sokoloff, K "Women, Children and Indus- trialisation in the Early Republic: Evidence from the Manu- facturing Censuses',Journal of Economic History”. Wiley. Belfast: I 982.

[9] Goodman, Jordan and Katrina Honeyman. "Women's Work, Gender Conflict, and Labour”. Economic History Review. USA: 1991.

[10] Honey, Maureen. "Remembering Rosie: Advertising Images of Women in World War II.” Westport. Greenwood: 1995.

[11] Johnson, Patricia E., 1951-. Hidden Hands : Working-Class Women and Victorian Social-Problem Fiction. Athens :Ohio University Press, 2001. Print.

[12] Katie, Stoneburner "women and industrialization" HIST 206 Women in European History. USA: 2005.

[13] Kerry, Harnett. “Appearing Modern: Women's Bodies, Beauty, and Power in 1920s America". Boston College. Boston College Electronic Thesis or Dissertation, 2009.

[14] King, C. David. Mariah Marvin, David Weitzman, and Toni Dwiggins. United States History. Addison-Wesley Publishing Company. USA: 1986. Print.

[15] Langee, Brenda. The Stock Market Crash of 1929: the end of prosperity. Chelsea House. New York: 2007.

[16] Laura, Fraser. Losing It: America's Obsession with Weight and the Industry that Feeds on it. Hudson Books. New York: 1997. Print.

[17] Lerner, M. Richard, Karabenick, A. Stuart. "Relations among physical attractiveness, body attitudes, and self-concept in male and female college students". Reilly and Lee Co. Chicago: 1973.

[18] Mai, Tracy. “To What Extent Were Women's Contributions in Industries of World War II Valued?". Howard High School. Ellicott City: n.d.

[19] Maria, Davidenko. "Discipline and Power in Women's Beauty Practices in Post-Soviet”. Crossroads. Russia: 2013.

[20] May, Ernest Richard. War, Boom and Bust: 1917-1932, The Life history of the United States. Time. United States of America: 1964. Print.

[21] Naomi Wolf. "The beauty myth”. Harper Collins. New York: 2002.

[22] Neff, Wanda Fraiken. Victorian Working Women: An Historical and Literary Study of Women in British Industries. New York: AMS Press, 1966. Print

[23] Scott, Sarah. "Influence of Cosmetics on the Confidence of College Women: An Exploratory Study". Hanover College. Indiana: n.d.

[24] Susannah, Walker. "Style and Status: Selling Beauty to African American Women". KY: University Press of Kentucky. Lexington: 2007.
[25] Tennyson, Lord Alfred. The princess. Guttenberg. USA: 1847. Print.

[26] The National WWII Museum. "Magazine Street" · National Museum. New Orleans: n.d.

[27] Turner, S. L. Hamilton. "The influence of fashion magazines on the body image". Satisfaction of college women. USA: 1997. 